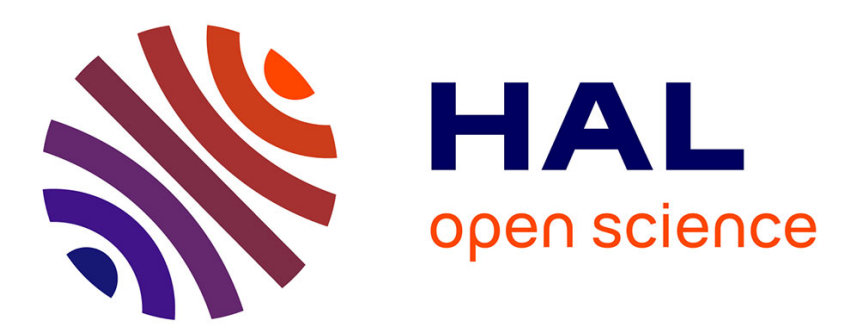

\title{
Design methods for the projection of uses for vulnerable people
}

\author{
Elena Elias, Marc-Eric Bobillier Chaumon, Michel Vacher
}

\section{To cite this version:}

Elena Elias, Marc-Eric Bobillier Chaumon, Michel Vacher. Design methods for the projection of uses for vulnerable people. 20th congress international ergonomics association, IEA, Aug 2018, Florence, Italy. pp.765-773, 10.1007/978-3-319-96071-5_80 . hal-01872576

\section{HAL Id: hal-01872576 https://hal.science/hal-01872576}

Submitted on 12 Sep 2018

HAL is a multi-disciplinary open access archive for the deposit and dissemination of scientific research documents, whether they are published or not. The documents may come from teaching and research institutions in France or abroad, or from public or private research centers.
L'archive ouverte pluridisciplinaire HAL, est destinée au dépôt et à la diffusion de documents scientifiques de niveau recherche, publiés ou non, émanant des établissements d'enseignement et de recherche français ou étrangers, des laboratoires publics ou privés. 


\title{
Design methods for the projection of uses for vulnerable people
}

\author{
Elena Elias ${ }^{1}$, Marc-Eric Bobillier Chaumon ${ }^{1}$, Michel Vacher ${ }^{2}$ \\ ${ }^{1}$ University of Lyon (Lyon 2) GREPS, Institute of psychology, \\ ${ }^{2}$ University of Grenoble Alpes, CNRS \\ elena.eliasduniv-lyon2.fr, marc-eric.bobillier-chaumoneuniv- \\ lyon2.fr, michel.vachereimag.fr
}

\begin{abstract}
The VOCADOM research project aims to design a new technology (voice control usable at home) to encourage the well-being and autonomy of the elderly with loss of autonomy at home. To guide design choices, we develop a user-centered design for all so that all actors are involved in the design process and we develop new methods of uses prospecting so that target profiles can project themselves in-to the use of an innovative device in ecological situation. We are in a process of methodological triangulation. Especially for the study of needs where through an ethnographic study we identify the problems encountered at home where the device can help. We ask end users and caregivers who are part of the eco system. After we use activity simulation methods to evaluate the acceptance, usefulness and usability of the device. This will allow us to improve the device so that it matches the real needs of users.
\end{abstract}

Keywords: Uses prospective, Assistant Ambient Living, Innovative methods

\section{Introduction}

Population ageing of the industrialised countries in the coming years will sharply increase and by correlation the number of people with loss of their autonomy will considerably increase. This situation will have economic impacts on society and will require additional places within specialised organizations. In the face of this societal context, technological devices are emerging to encourage home support. These must be codesigned for and by future users to be accepted. The Vodacom research project is part of this framework and aims to design a new technology (voice control usable at home, sensitive to the use's context and specificities of the person) to promote well-being and autonomy of the dependent elderly at home or persons with disabilities (visually impaired person). The user-centered design that we apply must implement methods adapted to these profiles. Which methods are adapted for this profile to understand their problems and their real needs at home and which methods can be mobilized so that these people can project themselves into the use of an innovative device? This article is organised in three parts. The first part presents the technological solutions envisaged to guarantee the well-being and the autonomy of the fragile persons. The second part 
presents the approach mobilized within the project. Finally, the third part is dedicated to the used methods.

\subsection{Loss of autonomy}

\subsection{Definition}

The ageing definition is very controversial. Some authors discuss the old age as a deterioration of the living conditions due to physical disorders [13] and others as a positive achievement of all abilities [23]. Ageing is still synonymous with fragility: physical, social [1-9-20], cognitive [31] and psychological [30-10]. These fragilities are different from one person to another and can be plural. The appearance of these disorders can cause a depression [32] and affect their autonomy and well-being. A person becomes dependent as soon as he needs help to carry out a daily life activity. Authors have thus identified AVQ and AIVQ [26], which are the daily life activities and the instrumental daily life activities that gather all the activities carried out in daily life. Within the CIRDO project [12], the AVQs were declined into eight dimensions, that is to say: the household activities, food, leisure, rest, mobility, treatments and hygiene, health and communication. The AGGIR score also enables to measure the autonomy level of a person, it is a scale graduated from 1 to 6 . The score 6 represents autonomous people requiring daily little help and 1 dependent people with important cognitive, physical, social problems that require constant help. People with loss of autonomy increasingly want to live at home [43]. Faced with these facts, there is the question of how to maintain these people at home, through which tools. A discipline then emerged, the gerontechnology, to try to meet these demands.

\subsection{Technological solutions for home support}

Gerontechnology is a discipline that aims to improve the daily life of the fragile elderly through technologies in the areas of health and autonomy. Devices then appeared as teleassistance, automatic pillbox, telepresence robots. However, these devices have obtained several criticisms due to a complexity of use [8] that causes misuse or non-use [24] and are sometimes considered as a dependence marker [13] and thus of stigmatization [21]. Devices such as teleassistance have limits [28], the ambient systems would enable to overcome this problem and do not impose new gestures and habits to integrate in everyday life. Thus, projects in the context of home support are turning to smart home through home automation and more recently the assistant ambient living. The concept of assistant ambient living (AAL) has been based and developed on smart home [33], the home is instrumented and equipped with innovative solutions enabling to fragile people such as the elderly to live the longest time at home [11]. AAL solutions have been developed to be accessible and ease to use. Indeed, acceptance by users is essential. Homes are thus equipped with micro, cameras and technological tools that measure people physiological data in a constant way. These devices would improve the elderly everyday life by giving them the opportunity to be more autonomous in their daily activities achievement. However, the existing solutions are still techno-push oriented and 
do not sufficiently take user needs [16] into account. In addition, a solution responds to a specific situation but cannot be transposed to another situation, which does not enable to respond to all the problems encountered by fragile people. The voice command thus appears to be suitable as an interaction solution for people having difficulties to move or sight problems [38]. Voice activated personal assistant (VAPA) have developed since the 90s and are booming because they have become more efficient thanks to their deep learning and artificial intelligence they have known a significant improvement. The most frequently used VAPAs are Apple's Siri, Amazon's Alexa, Microsoft's Cortana and Google Assistant. The voice assistant would be used in priority in a private place so that the information would not be heard [18]. The enthusiasm of these devices comes from an anthropomorphic need [37], indeed, the voice assistant would be perceived as a companion because words are increasingly recognized. But this can cause confusion among users who perceive these devices as systems enable to under-stand human language. In reality, their abilities are limited, indeed, these devices have their own language, the user must comply. These devices emerge even within home in particular with Amazon Echo in 2014, Google Home in 201 in the United States, and this is the beginning Google Home has just appeared in France and other operators will develop. One of the limits of these devices is that data is released and collected outside the home.

\section{Approach}

\subsection{Vocadom project}

The Vodacom project has the purpose of forcing knocks presented above. From an acceptability point of view, the device must satisfy the real needs of the elderly and adapt to their functional limits. From a technical point of view the device must be able to recognize the elderly voices and build an interaction syntax so that it is available from this profile. Also, the Vodacom device focuses on providing an enabling devices [4] to supplement encountered problems.

\subsection{Design}

We want to combine two design approaches. Namely, the user-centered design (UCD) approach that responds ISO 9241-11 and ISO 9241-210 (before ISO 13407) standards, emerges from ergonomics of human-system interfaces (HSI). This approach aims to understand the use context by involving end-users in the design process to design a device respecting the usability criteria. It mobilises various and rigorous methods of data collection to guide design choices. However, this approach has its limits [26], indeed the devices resulting from this user-centered design correspond to the global population needs, leaving aside minorities who may have handicaps or frailties. Moreover, a person can be polyhandicap. The so-called universal design is aimed to designing devices that can be used by the largest number [29]. Seven principles [40] have been defined so that the designed device does not stigmatize people and that it can be used and accessible by everyone with adaptation to individual abilities. Lespinet-Najib et al. 
[27] argue that these two types of design should be coupled to develop solutions adapted to the real needs and the use context and that they can be used by all whatever their functional limitations. We are in the context of the Vocadom project, indeed the elderly have interindividual variations that must be taken into consideration, for example, an elderly person may be hearing and visually impaired. So, we want to be part of these two design approaches, we want to develop a device dedicated to the elderly by taking their multiple fragilities into account but one of the conditions is that the person can use this system and this person has not a serious cognitive pathology. The project is in the field of home care, it is essential to involve the actors that form the ecosystem in the design process [4-15-35]. Caregivers and professionals can become prescribers and proscribers of the device use. So, they are involved from the definition of needs, we speak from co-design.

\section{$2.3 \quad$ Co-design}

We rely on the definition proposed by Darse et al. (2009) which defines the concept of co-design as all of actors that collaborates on a common project to solve a problem. Codesign is used in living labs, which mobilize experts from different fields to develop innovative technological solutions. In Health and Autonomy, living labs are made up of multidisciplinary team with experts from different fields and end users who mobilize resources, tools, platforms and methods [36]. All the actors are involved upstream of design. To guarantee the coordination between all the actors, tools of assistance to the design are created, such as tools assisted by computers [22], the rapid prototyping, models... These objects are named intermediary designed objects by Jeantet [25] who serve as a support for actors so that they can exchange and share their point of view. They can be considered as artefacts [34] used as support even as partners [25] between the different actors involved in a design process. Intermediary objects are thus intended to guarantee exchanges and build collective action [42] by helping to compromise joint action and not only the communication and transmission of information. We get closer to the approach proposed in the living labs in health and autonomy because we call on different actors within the design cycle and we are in an innovative process. However, we distinguish ourselves of these concepts because we want to deploy new methods of prospecting for uses in situ to be closer to ecological situations. To promote coordination between all the actors, we have developed "all expertise" intermediary objects as support in the design cycle. 


\section{$3 \quad$ Methodology}

\subsection{Methodological triangulation}

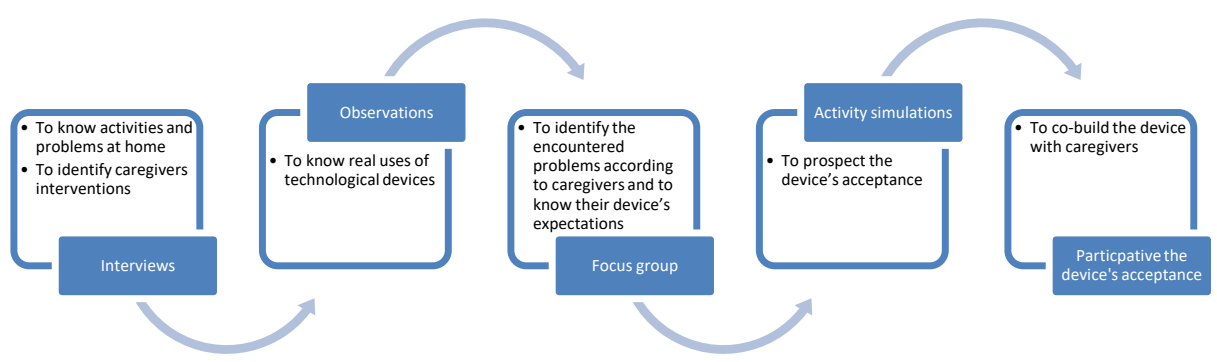

Fig. 1. Methods within the Vocadom project

In the field of ergonomic psychology, the intention and the maintenance of uses are particularly measured by social acceptability questionnaires such as the UTAUT 2 model [41], which enables to predict attitudes (favourable or not) towards technologies on different socio-cognitive indicators (behavioural control, subjective norms, behavioural intention...). However, this type of method is not suitable for the elderly because of a misunderstanding of measurement scales or a social desirability bias [39]. Moreover, it seems difficult for these elderly people to project themselves into the futureprobable use of such an innovative technology, while they have no experience with equivalent systems. Therefore, we come within the scope of prospective ergonomics which aims to identify real needs to anticipate future uses of a device by mobilizing different methods [7]. This is why, in our project, we use a methodological triangulation approach [19] using innovative methods that can be used with the elderly and which are part of the approach of acceptation located, the situated acceptance [5] which apprehends, in life context, the real activity and use of the technical object. Use and practice are then to be considered as determinant of acceptance. The idea is not so much that home actors have a favourable representation of the technical object, but that these technologies have indeed a favourable effect on the individual and collective activity of these people [3]. We mobilize the situated acceptance which is based on activity models [5] that the use and the practice are determinant of what the technology will be and what it will bring. In other words, we cannot anticipate the possible effects of a technology out of any context of use. It is his concrete implementation that will enable to evaluate his contributions and the effective acceptance; taking activity and human behaviour as well as environmental, social and situated of usage.

\subsection{Ethnography of the activity}

To understand the real needs and the socio-domestic context of the fragile people, we carried out an ethnography thanks to interviews and observations with these people. It 
is a comprehensive approach which enables to understand practice's life, mobilized resources and daily constraints of the person in order to identify and evaluate, on the one hand, the different activities (in terms of nature, but also cost, difficulties, organizational efficiency required -individual \& collective-, etc.) and to define, on the other hand, the meaning these tasks have for the person (what do they represent for the person and for its different life systems: personal, social, domestic, family...). This ethnographic and anthropocentric approach proves to be indispensable in a user-centered design approach so that the device not only responds to real needs of the target population, but also enables the development of the activity, giving (again) the power to act and action capacities to these prevented public [6]. We are also interested in people who regularly intervene at home as these will also be impacted by the device implementation and they can become prescribers or proscribers of the device use. Caregivers are sought as soon as needs are studied. The analysis of their activity at home (what they do at home, alone / with the elderly person, the way that activities are organized, co-build with seniors...), focus groups are also put in place so that caregivers can share their experiences and opinions for home support. This technique enables us to identify roles and tasks performed with people, and to collectively con-sider the role the technical artefact can play and must play in the home activity system. The ethnographic study identified problematic situations that were presented to the teams of the Laboratory of Computer Science in Grenoble during co-design sessions using intermediary design objects such as personas, reference context illustrations and videos of real uses of technological tools. The idea is each group of experts have a common knowledge base easily interpretable. Communicating objects to system experts have had the role of confronting them to the real situations lived by the people and to project them-selves in their life contexts. To these objects of communication, fully realize their function it is necessary they are mobilized during participative sessions. Indeed, only distributing information through these objects is not enough because it is through these objects that we were able to exchange and make decisions collectively. These co-design sessions enabled to classify the identified problems according to three categories, outside the project, realisable or to be studied. At the end of this first phase, we were able to define potential services for the Vocadom device.

\subsection{Activity simulation}

To evaluate needs we have identified, we wish to mobilize the activity simulation method used in the organization-simulation approach [2] to co-build the usage scenarios with future users taking domestic organization and future uses into account. It is implemented with tangible materials such as models and figurines. We will thus create a 3D miniature house that will be customizable and will represent the home of the person. We will use this tool at home so that the person can project themselves with the Vocadom device. In fact, in general, solicited people who agree to carry out experiments in laboratories such as living labs are autonomous people who are not isolated at home. With the miniature house, we will be able to question the persons at their home, it is not the people who come to us but we who come to them in their context of life. Following the ethnographic study, we were able to identify that people most in need of 
the Vocadom device would be the elderly with loss of autonomy (GIR 4 and 3) and the elderly with severe visual deficiency who would disable to move within a research laboratory. With caregivers, we use the method of participative design sessions that enables through scenarios, modelling, to project himself in the device use and identify desired features and interaction modes. In a second step, we will evaluate the device within a housing equipped with home automation, Domus [17] thanks to the technique of the $\mathrm{Oz}$ Wizard, which enables to simulate a certain number of functionalities to evaluate the acceptability and usability of the device. This technique enables to get closer to the interaction with the device but we also want to perform this technique at home with a demonstrator.

\subsection{Conclusion}

This article introduced the design approach that we implement as part of the Vocadom project which aims to develop a voice control solution that enables older people to be more autonomous at home by moving in a enabling home. We realize a user-centered design for all, mobilizing a certain number of actors. To apprehend the socio-domestic and socio-technical context of persons, we have set up a methodological triangulation by mobilizing interviews, observations and focus groups. This first comprehensive study enabled to identify problematic situations lived by the persons, we then carried out working sessions with the system experts to identify possible services for Vocadom to mitigate these problems. To ensure that these services are useful and accepted, we use the method of home activities simulations and in a smart home equipped with home automation, to guide the best design choices.

\section{Aknowledgement}

The Vodacom project is funded by the National Agency for Research (ANR) and gathers different scientific partners: the GETAPS laboratories of the University of Grenoble-Alpes, GRePS of the University of Lyon and INRIA of Nancy.

\section{References}

1. Ballinger, C., \& Payne, S. (2002). The construction of the risk of falling among and by older people. Ageing \& Society, 22(3), 305-324.

2. Barcellini,F., Van Belleghem, L., and Daniellou, F., 2013. Les projets de conception comme opportunité de développement des activités. In Ergonomie constructive. Presses universitaires de France, 191-206.

3. Bobillier-Chaumon, M-E. (2013). Conditions d'usage et facteurs d'acceptation des technologies dans l'activité: questions et perspectives pour la psychologie du travail (Habilitation à Diriger la Recherche). Université Pierre-Mendès-France, Grenoble.

4. Bobillier-Chaumon, M-E. et al. (2014). Concevoir une technologie ambiante pour le maintien à domicile : une démarche prospective par la prise en compte des systèmes d'activité. Le travail humain, 77(1), 39-62. 
5. Bobillier Chaumon, M-E., (2016). L'acceptation située des technologies dans et par l'activité : Premiers étayages pour une clinique de l'usage. Psychologie du Travail et des Organisations 22, 1 (2016), 4-21.

6. Bobillier Chaumon, M-E, Clot, Y. (2016). Clinique de l'usage : Les artefacts technologiques comme développement de l'activité. Synthèse Introductive au dossier. Activités 13, 2 (2016).

7. Brangier, Robert, J-M. 2012. L'innovation par l'ergonomie : éléments d'ergonomie prospective. Innovation, connaissances et société : vers une société de l'innovation (2012), 59-82.

8. Caradec, V. (1999). Vieillissement et usage des technologies. Une perspective identitaire et relationnelle. Réseaux, 17(96), 45-95. https://doi.org/10.3406/reso.1999.1059

9. Caradec, V. (2003). Comportements culturels de la population âgée. Empan, 52(4), 54. https://doi.org/10.3917/empa.052.0054

10. Caradec, V. (2007). L'épreuve du grand âge. Retraite et société, 52(3), 11-37. Récupéré du site sur http://www.cairn.info/revue-retraite-et-societe-2007-3-page-11

11. Chen, L., Nugent C. (2009) Ontology-based activity recognition in intelligent pervasive environments. International Journal of Web

12. CIRDO ( « Compagnon Intelligent Réagissant au Doigt et à l'Oeil » - financements ANR et CNSA) réunit plusieurs partenaires industriels et scientifiques issus de différentes disciplines : Laboratoires de traitement de l'image et du langage (GETALP, LIRIS) et laboratoire en psychologie de la santé, ergonomique et du travail (GRePS). Partenaires industriels TECHNOSENS, CATEL, IRSAP et FSI

13. Clement, S., Rolland, C. et Thoer-Fabre, C. (2005). Usages, normes, autonomie : analyse critique de la bibliographie concernant le vieillissement de la population. https://f.hypotheses.org/wp-content/blogs.dir/2438/files/2016/02/Rapport-Usages-Normes-Autonomie-1

14. Darses, F.2009. Résolution collective des problèmes de conception. Le travail humain 72,1 (2009), 43-59.

15. Davin, B., Paraponaris, A. et Verger, P. (2008). Entraide formelle et informelle: Quelle prise en charge pour les personnes âgées dépendantes à domicile ? Gérontologie et société, 127(4), 49-65. doi:10.3917/gs.127.0049

16. Desai A. and Jhaveri. R (2017) A Review on Applications of Ambient Assisted Living. International Journal of Computer Applications 176(8):1-7

17. Domus, Plateforme expérimentable du Laboratoire Informatique de l'Université Grenoble Alpes domus.liglab.fr

18. Easwara Moorthy, A., \& Vu, K.-P. L. (2015). Privacy Concerns for Use of Voice Activated Personal Assistant in the Public Space. International Journal of Human-Computer Interaction, 31(4), 307-335. https://doi.org/10.1080/10447318.2014.986642

19. Flick, U. (1992). Triangulation Revisited: Strategy of Validation or Alternative?.Journal of the Theory of Social Behavior, 22(2),176-197.

20. Freund, A. M., Baltes, P. B. (2000). The orchestration of selection, optimization and compensation: An action-theoretical conceptualization of a theory of developmental regulation. In W. J. Perrig \& A. Grob (Eds.), Control of human behavior, mental processes, and consciousness: Essays in honor of the 60th birthday of August Flammer (pp. 35-58). Mahwah, NJ: Lawrence Erlbaum

21. Goffman E. (1977) Les stigmates : Les usages sociaux des handicaps Paris : Ed. de Minuit.

22. Gorges, I. (1996) The impact of society on CAD research in the USA, France and Germany, 1955 through 1985. The Role of Design in the Shaping of Technology, COST A 4 (1996), $155-83$.

23. Guérette, M-J., Caradec, V., Bergman, H., Joanette, Y et Blanchard, F. (2006). La vieillesse, c'est le déclin, on n'y peut rien. Santé, Société et Solidarité, (1), 23-31. 
24. Hem, C. (2015). Le téléphone, un artefact témoin du bien-être des personnes-âgées (thèse de doctorat, Université de Grenoble).

25. Jeantet, A. (1998). Les objets intermédiaires dans la conception. Eléments pour une sociologie des processus de conception. Sociologie du travail (1998), 291-316.

26. Lawton, M.P., \& Brody, E.M. (1969). Assessment of older people: Self-maintaining and instrumental activities of daily living. The Gerontologist, 9 (3), 179-186.

27. Lespinet-Najib, V., Roche, A., \& Chibaudel, Q. (2017). Santé et handicap: d'une conception centrée « utilisateur » à la conception universelle. In Annales des Mines-Réalités industrielles (p. 25-27). FFE.

28. Lie, M., \& Brittain, K. (2016). Technologie et confiance. Retraite et société, (3), 47-72.

29. Mace R., Definitions : accessible, adaptable et universal design, The center for universal Design, Raleigh, 1990

30. Michel, C., Bobillier-Chaumon, M-E. et Tarpin-Bernard, F. (2009). Fracture numérique chez les seniors du 4ème âge. Observation d'une acculturation technique. Les Cahiers du numériques, 5(1), 147-168.

31. Moget, C., Bonnardel, N., \& Galy-Marie, E. (2014). Ergonomie prospective et âge : proposition de méthodes nouvelles pour la conception d'un système de maintien à domicile. Le travail humain, 77(3), 231. https://doi.org/10.3917/th.773.0231

32. Monfort, J. (2001). Spécificités psychologiques des personnes très âgées. Gérontologie et société, 98(3), 159-187. doi:10.3917/gs.098.0159

33. Nehmer, J., Becker, M., Karshmer, A., Lamm, R., (2006) Living assistance systems: an ambient intelligence approach. Proceedings of the 28th international conference on Software engineering. pp. $43-50$

34. Norman, D. (1993) Les artefacts cognitifs. Raisons pratiques 4, 15-34

35. Picard, R., Poilpot, L., Benoit, A-M., Charrat B., Comtet, G., Pallot, M., Soyez, S., Vial, A. (2011) Pertinence et valeur du concept de « Laboratoire vivant»(Living Lab) en santé et autonomie. Rapport CGEIET (2011)

36. Picard, R. et al. 2017. La co---conception en Living Lab santé et autonomie 1 : Concept, méthodes et outils. iSTE editions.

37. Poirier, F. (2017). Quelle modalité pour l'interaction avec les petits appareils mobiles et vestimentaires: texte ou vocal? Comment choisir entre clavier et assistant personnel? In 29ème conférence francophone sur l'Interaction Homme-Machine (p. A-67).

38. Portet F., Vacher M., Golanski C., Roux C., Meillon B. (2013) Design and evaluation of a smart home voice interface for the elderly: acceptability and objection aspects, Personal and Ubiquitous Computing, 17(1): 127-144, 2013.

39. Reerink-Boulanger,J., (2012). Services technologiques intégrés dans l'habitat des personnes âgées : examen des déterminants individuels, sociaux et organisationnels de leur acceptabilité. Ph.D. Dissertation. Université Rennes 2.

40. The Center for Universal Design. (1997). The Principles of Universal Design (Version 2.0). Raleigh, NC: NC State University, Author.

41. Venkatesh,V., Thong, J., and Xu, X., 2012. Consumer Acceptance and Use of Information Technology : Extending the Unified Theory of Acceptance and Use of Technology. (2012).

42. Vinck, V., Laureillard, P. (1996) Coordination par les objets dans les processus de conception. In Représenter, Attribuer, Coordonner. 289-295.

43. Wiles, J. L., Leibing, A., Guberman, N., Reeve, J., \& Allen, R. E. S. (2012). The Meaning of " Aging in Place " to Older People. The Gerontologist, 52(3), 357-366. https://doi.org/10.1093/geront/gnr098 